\title{
PENGARUH PENGGUNAAN MEDIA SIMULASI PHET (PHYSICS EDUCATION TECHNOLOGY) TERHADAP HASIL BELAJAR FISIKA
}

\section{THE EFFECTS OF USING PHET (PHYSICS EDUCATIONS TECHNOLOGY) MEDIA SIMULATION TO RESULT OF STUDENTS PHYSICS}

\author{
Rozi Saputra, Susilawati dan Ni Nyoman Sri Putu Verawati \\ Program Studi Pendidikan Fisika FKIP Universitas Mataram, Mataram, Indonesia \\ Email: rozisaputra010@gmail.com
}

Diterima: 13 November 2019. Disetujui: 3 Desember 2019. Dipublikasikan: 2 Maret 2020

\begin{abstract}
Abstrak: Penelitian ini bertujuan untuk mengetahui pengaruh penggunaan media simulasi PhET (physics education tehnology) terhadap hasil belajar fisika peserta didik SMA Negeri 1 Kediri tahun ajaran 2018/2019. Jenis penelitian ini adalah quasi experiment dengan desain penelitian non-equivalent control group design. Populasi penelitian ini adalah seluruh siswa kelas XI MIA SMAN 1 Kediri dengan jumlah 64 peserta didik, tehnik pengambilan sampel menggunakan cluster random sampling dan diperoleh kelas XI MIA 1 sebagai kelas eksperimen sebanyak 21 orang dan kelas XI MIA 2 sebagai kelas Kontrol sebanyak 20 orang. Kelas eksperimen diberikan perlakuan pembelajaran dengan model pembelajaran langsung menggunakan media simulasi PhET (Physics Education Tehnology) sedangkan kelas kontrol menggunakan pembelajaran konvensional. Uji coba instrument tes hasil belajar telah memenuhi syarat diantaranya, uji validitas, reliabilitas, tingkat kesukaran dan daya beda. Sehingga diperoleh sebanyak 25 soal valid dan 5 soal tidak valid dari 30 soal yang diujikan, kemudian soal tersebut diberikan saat melakukan tes awal dan tes akhir. Setelah didapatkan hasil tes akhir kedua kelas homogen dan terdistribusi normal hipotesis penelitian diujikan dengan uji-t dengan taraf signifikan 5\% dan diperoleh hasil thitung sebesar 4,12 dan $t_{\text {tabel }}$ sebesar 2,02 sehingga dapat dikatakan bahwa nilai thitung lebih besar dari $\mathrm{t}_{\text {tabel. }}$. Berdasarkan hasil tersebut dapat disimpulkan bahwa terdapat pengaruh penggunaan media simulasi PhET (Physics Education Technology) terhadap hasil belajar fisika peserta didik.
\end{abstract}

Kata kunci: Media simulasi PhET (physics education tehnology), hasil belajar

\begin{abstract}
Abstact: The purpose of this study is to find out the effects of PhET (physic education technology) media simulation to the results of students' physic in SMA Negeri 1 Kediri academic year 2018/2019. This study is quasi experiment with non-equivalent control group design of study. The population of this study is all of the students in XI MIA SMAN 1 Kediri which consists of 64 students, the technic use in collecting the sample is Cluster random sampling which XI MIA 1 as experiment class has 21 students, and XI MIA 2 as control class that has 20 students. The Experiment class was given learning model using PhET simulation media, while control class using conventional learning. The test of the students' learning results has completed the requirements, i.e validity test, reliability, level of difficulties, and different ability. The researcher got 25 valid questions and 5 invalid questions from 30 questions was being tested, then those questions will be given on the first and the last test. After the last results collected, both classes are homogeneous and distributed normally, the hypothesis which the study being tested using T-test with 5\% significant, T solve 4.12 , Ttable 2.02 so we can say that $\mathrm{T}$ solve is more than the T table. Based on the results we can conclude that there's effect in using PhET simulation media to students' physics results.
\end{abstract}

Keywords: Media simulation PhET (physics education tehnology), learning result

\section{PENDAHULUAN}

Ilmu pengetahuan alam (sains) merupakan suatu cabang ilmu untuk mengetahui keteraturan alam baik fakta, konsep, prinsip, proses penemuan maupun suatu sikap ilmiah [1].

Fisika merupakan bagian dari ilmu pengetahuan alam (IPA) atau sains yang menerangkan berbagai gejala kejadian alam, yang memungkinkan penelitian dengan percobaan, pengukuran apa yang didapat, penyajian secara matematis dan berdasarkan peraturan-peraturan umum. Fisika tidak hanya berisi tentang teori-teori atau rumus-rumus untuk di hafal, akan tetapi dalam fisika berisi banyak konsep yang harus dipahami secara mendalam.

Berdasarkan hasil observasi didapatkan beberapa permasalahan dalam pembelajaran fisika, diantaranya peserta didik masih beranggapan bahwa mata pelajaran fisika itu sulit, banyak rumus, membosankan dan masih minimnya alat percobaan yang ada serta laboratorium komputer yang cukup memadai namun tidak dimanfaatkan dengan baik, selain itu peserta didik kurang aktif dalam mengajukan pertanyaan apabila kurang mengerti dengan penjelasan yang disampaikan oleh guru. Sehingga mengakibatkan hasil belajar peserta didik rendah. Untuk memahami konsep-konsep fisika 
akan terasa sulit bagi peserta didik apabila hanya mendengarkan dan mencatat penjelasan guru saja. Oleh karena itu, dibutuhkan suatu media pembelajaran yang berkaitan dengan penjelasan konsep-konsep fisika tersebut.

Salah satu media pembelajaran yang dapat digunakan oleh peserta didik dalam menunjang hasil belajar fisika peserta didik adalah media simulasi $\mathrm{PhET}$. Media PhET merupakan simulasi interaktif fenomena-fenomen fisis berbasis riset yang dapat mendukung pendekatan interaktif dan kontruktivis, memberikan umpan balik dan menyampaikan pesanpesan atau informasi dalam pembelajaran fisika.

Penggunaan media simulasi PhET sebagai media pembelajaran juga telah banyak diteliti dan menunjukkan persentasi keberhasilan yang signifikan. Diantaranya penelitian yang dilakukan oleh Nurhayati, dkk [2] menyatakan bahwa hasil belajar peserta didik yang diajarkan dengan metode demontrasi berbantuan media animasi software PhET lebih baik dari pada hasil belajar peserta didik dengan menggunakan metode konvensional. Terjadinya perbedaan hasil belajar peserta didik dikarenakan metode demonstrasi berbantu media animasi software PhET dapat menarik perhatian peserta didik untuk mengikuti pembelajaran dikelas dan peserta didik tidak hanya membayangkan secara abstrak tentang konsep-konsep fisika yang diajarkan oleh guru. Begitu juga penelitian yang dilakukan oleh Yuafi [3] menyimpulkan bahwa terdapat pengaruh penerapan model pembelajaran langsung yang menggunakan media pembelajaran Physics Education Technology (PhET) terhadap hasil belajar peserta didik dikarenakan dapat menciptakan pembelajaran yang aktif, kreatif, efisien dan menyenangkan. Hal ini sesuai dengan zahara, dkk [4] menyimpulkan bahwa pembelajaran dengan media simulasi PhET (Physics Education Technology) dapat meningkatkan hasil belajar dan keterampilan berfikir kritis peserta didik. Peningkatan hasil belajar peserta didik dengan menggunakan media simulasi PhET dikarenakan dapat melibatkan peserta didik dalam aktivitas pembelajaran.

Media pembelajaran merupakan segala sesuatu yang dapat digunakan untuk mengantarkan atau menyampaikan pesan, berupa sejumlah pengetahuan, keterampilan, dan sikap-sikap kepada peserta didik sehingga peserta didik itu dapat menangkap, memahami, dan memiliki pesan-pesan dan makna yang disampaikan melalui suatu gambar, foto, permainan ataupun animasi [3]. Menurut Arifin [5], media pembelajaran merupakan perantara untuk memudahkan proses belajar mengajar agar tercapai tujuan pengajaran secara efektif dan efisien. Beberapa pendapat diatas, dapat disimpulkan bahwa yang dimaksud dengan media pembelelajaran adalah segala sesuatu yang dapat digunakan untuk menyampaikan pesan atau informasi dalam sebuah pembelajaran demi tercapainya tujuan pembelajaran. Salah satu media pembelajaran yang dapat menyampaikan pesan atau informasi dalam sebuah pembelajaran adalah media simulasi PhET. Dengan media simulasi PhET juga dapat menjelaskan fenomena fenomena yang abstrak atau tidak dapat dilihat oleh mata terbuka.

Physics Education Technology (PhET) adalah simulasi yang dibuat oleh (University Of Colorado) yang berisi simulasi pembelajaran fisika, biologi, dan kimia untuk kepentingan pembelajaran dikelas atau belajar individu. Kelebihan simulasi PhET yaitu menekankan hubungan antara fenomena kehidupan nyata dengan ilmu yang mendasari, mendukung pendekatan interaktif dan kontruktivis, memberikan umpan balik, dan menyediakan tempat kerja kreatif [6].

Menurut Yuafi [3] Physics Education Technology (PhET) adalah software simulasi interaktif fisika yang tersedia pada situs yang dapat dijalankan secara online atau offline. Dengan menggunakan software tersebut tentunya dapat menciptakan pembelajaran yang aktif, kreatif, efektif dan menyenangkan. Di dalam media ini dapat ditampilkan suatu materi yang bersifat abstrak dan dapat dijelaskan secara langsung oleh media ini sehingga peserta didik dengan mudah memahami materi tersebut [7].

Media simulasi PhET adalah media pembelajaran yang di dalamnya terdapat beberapa materi simulasi pembelajaran fisika untuk kepentingan pengajaran di kelas atau dapat digunakan untuk kepentingan belajar individu. Simulasi yang disediakan PhET sangat interaktif dan mengajak peserta didik untuk belajar dengan cara mengeksplorasi secara langsung. Software PhET ini memuat suatu animasi fisika yang abstrak atau tidak dapat dilihat oleh mata terbuka. Untuk eksplorasi secara kuantitatif, software PhET ini memiliki alat-alat ukur di dalamnya seperti penggaris, stopwatch, voltmeter dan termometer [8].

Kelebihan simulasi PhET yakni dapat melakukan percobaan secara ideal, yang tidak dapat digunakan dengan menggunakan alat dan bahan yang sesungguhnya [9].

Belajar adalah suatu proses untuk merubah tingkah laku sehingga diperoleh pengetahuan dan keterampilan untuk menjadi lebih baik dari sebelumnya. Belajar pada hakikatnya adalah "perubahan" yang terjadi dalam diri seseorang setelah melakukan aktifitas tertentu [10]. Hasil belajar merupakan bagian terpenting dalam pembelajaran. Menurut Anni dalam Khadira, dkk [11] hasil belajar merupakan perubahan perilaku yang diperoleh peserta didik setelah mengalami aktifitas belajar.

Menurut Suprijono [12] hasil belajar sebagai pola-pola perbuatan, nilai-nilai, pengertianpengertian, sikap-sikap, apresiasi dan keterampilanketerampilan. Menurut Bloom dalam Nanang [13] perubahan perikalu dalam belajar (hasil dari belajar) 
mencakup seluruh aspek pribadi peserta didik, yaitu kognitif, afektif, dan psikomotor.

\section{METODE PENELITIAN}

Jenis penelitian yang digunakan adalah kuasi eksperimen. Pada kuasi eksperimen peneliti tidak memiliki kekuasaan untuk memanipulasi subjek, artinya random kelompok biasanya dipakai sebagai dasar untuk menetapkan sebagai kelompok perlakuan dan kontrol [14]. Kegunaan penelitian kuasi eksperimen untuk mengetahui ada tidaknya pengaruh variabel tertentu dengan variabel lain dalam kondisi dikendalikan.

Penelitian ini melibatkan variabel bebas yaitu pembelajaran menggunakan media simulasi PhET (Physics Education Technology), variabel terikat yaitu hasil belajar fisika, dan variabel kontrol yaitu Adapun variabel kontrol dalam penelitian ini adalah materi pembelajaran, instrumen pembelajaran yang meliputi silabus, rencana pelaksanaan pembelajaran (RPP), lembar kegiatan peserta didik (LKPD), kisi-kisi tes, soal tes hasil belajar, serta alokasi waktu pembelajaran dikondisikan.

Penelitian ini dilakukan di SMA Negeri 1

Kediri Kabupaten Lombok Barat, NTB. Populasi penelitian adalah seluruh peserta didik kelas XI MIA SMAN 1 Kediri tahun ajaran 2018/2019 yang berjumlah 64 peserta didik dan terbagi dalam 3 kelas. Teknik pengambilan sampel dalam penelitian ini yaitu menggunakan teknik cluster random sampling. Teknik kelompok atau rumpun (cluster) digunakan apabila populasi atau sampel yang tersedia adalah berupa unit-unit rumpun dalam populasi [14]. Pengambilan sampel diambil secara acak kelompok individu dalam hal ini adalah kelas XI yang telah tersedia di SMA Negeri 1 Kediri. Sampel dalam penelitian ini adalah kelas XI MIA 1 dengan jumlah peserta didik 21 orang sebagai kelas eksperimen dengan model pembelajaran langsung menggunakan media simulasi PhET (Physics Education Technology) dan kelas XI MIA 2 dengan jumlah peserta didik 20 orang sebagai kelas kontrol menggunakan pembelajaran konvensional.

Instrumen yang digunakan adalah tes pilihan ganda sebanyak 25 soal. Instrumen tes pilihan ganda sebelum digunakan harus memenuhi beberapa syarat yaitu uji validitas, reliabilitas, tingkat kesukaran soal dan daya beda. Uji statistik parametrik yang digunakan adalah uji-t dengan membandingkan kedua mean pada taraf signifikan $5 \%$.

\section{HASIL DAN PEMBAHASAN}

Penelitian ini bertujuan untuk mengetahui pengaruh penggunaan media simulasi PhET (Physics Education Technology) terhadap hasil belajar fisika peserta didik SMA Negeri 1 Kediri Kabupaten Lombok Barat pada kelas XI MIA semester 1 tahun pelajaran $2018 / 2019$. Penelitian ini menggunakan dua kelompok sampel yaitu kelas XI MIA 1 berjumlah 21 orang peserta didik sebagai kelas eksperimen dan kelas XI MIA 2 berjumlah 20 orang peserta didik sebagai kelas kontrol. Perlakuan yang diberikan kepada peserta didik kelas eksperimen adalah menggunakan media simulasi PhET (Physics Education Technology) sedangkan kelas kontrol menggunakan pembelajaran konvensional.

Hasil belajar fisika peserta didik yang dimaksud pada penelitian ini adalah hasil belajar pada ranah kognitif $\mathrm{C} 1$ sampai $\mathrm{C} 6$ (pengetahuan, pemahaman, penerapan, analisis, sintesis dan evaluasi), pada ranah afektif dan psikomotor sebagai data pendukung untuk kelas eksperimen. Pengambilan data untuk kemampuan awal dan akhir dilakukan dengan memberikan tes, yaitu tes awal dan tes akhir berupa tes obyektif dengan bentuk tes pilihan ganda sebanyak 25 soal. Sebelum mendapatkan 25 soal, peneliti melakukan uji validitas soal pada kelas XII MIA 2 dengan jumlah 30 soal pilihan ganda. Pada hasil uji coba instrumen didapatkan 25 soal diterima dan 5 soal ditolak. Sehingga peneliti menyimpulkan 25 soal tersebut valid untuk diberikan ke peserta didik pada saat melakukan tes awal dan tes akhir.

Peserta didik diberikan tes awal terlebih dahulu untuk mengetahui kemampuan awal peserta didik dari kedua sampel. Data hasil tes awal menunjukkan bahwa nilai rata-rata peserta didik pada kelas eksperimen sebesar 30,10 dan kelas kontrol sebesar 33,20. Berdasarkan uji homogenitas dan uji normalitas dari data tes awal hasil belajar, didapatkan bahwa kedua kelas homogen dan terdistribusi normal. Setelah mengetahui homogenitas dan normalitas sebaran data awal, kemudian kedua kelas diberi perlakuan. Kedua kelas diberikan perlakuan selama tiga kali pertemuan dengan alokasi waktu selama 90 menit (2 jam pelajaran). Perlakuan yang diberikan kepada kelas eksperimen adalah penggunaan media simulasi PhET (Physics Education Technology) pada materi Elastisitas dan Hukum Hooke sedangkan kelas kontrol menggunakan pembelajaran konvensional dengan materi yang sama.

Pembelajaran yang diterapkan di kelas ekperimen pada pertemuan pertama yakni, peserta didik diberikan LKPD 1 untuk menganalisis sifat elastis dan sifat plastis benda yang di kerjakan secara berkelompok. Peserta didik mengamati sifat benda dengan memberikan gaya tarik pada sebuah benda. Apabila benda kembali ke keadaan semula setelah gaya tarik dihilangkan maka benda dapat dikatakan elastis. Sebaliknya jika benda tidak kembali ke keadaan semula setelah gaya tarik dihilangkan maka benda dikatakan plastis. Pada pertemuan kedua peneliti mengenalkan media simulasi PhET untuk digunakan oleh peserta didik dalam melakukan percobaan. Sebelum melakukan percobaan peneliti terlebih dahulu menjelaskan 
bagaimana melakukan percobaan menggunakan media simulasi PhET. Sehingga peserta didik dapat melakukan percobaan hukum hooke secara mandiri dengan kelompoknya. Peserta didik mengamati pegas pada media simulasi PhET yang telah diberikan gaya tarik bertambah secara bertahap dan hasil pengamatan yang di dapat di tulis pada lembar kerja peserta didik (LKPD 2). Salah satu kelompok mempersentasikan hasil pengamatan yang didapat, kemudian kelompok lainnya menanggapi hasil persentasi yang sudah dilakukan. Sehingga dapat disimpulkan bahwa semakin besar gaya tarik yang diberikan pada pegas sebanding dengan pertambahan yang di alami oleh pegas. Selain melakukan percobaan dengan menggunakan media simulasi PhET, peserta didik juga diberikan latihan soal untuk menguatkan konsep yang didapatkan pada saat melakukan percobaan.

Pertemuan selanjutnya peserta didik melakukan percobaan menggunakan media simulasi PhET secara mandiri dengan mengikuti langkahlangkah yang ada pada LKPD 3 tentang percobaan rangkain pegas seri dan rangkaian pegas parallel. Peserta didik mengamati pertambahan panjang pegas pada rangkaian seri dan rangkaian parallel dengan menambahkan konstanta pegas secara bertahap. Kemudian peserta didik mencatat hasil pengamatan yang didapatkan. Salah satu kelompok mempersentasikan hasil pengamatan yang didapat, kemudian kelompok lainnya menanggapi hasil persentasi yang sudah dilakukan. Sehingga dapat disimpulkan bahwa semakin besar konstanta pegas yang digunakan, maka pertambahan panjang yang di alami pegas semakin berkurang. Sebaliknya semakin kecil konstanta pegas yang digunakan, maka pertambahan panjang yang dialami pegas semakin bertambah. Selain melakukan percobaan dengan menggunakan media simulasi PhET, peserta didik juga diberikan latihan soal tentang rangkaian seri dan rangkaian parallel pada pegas guna mempersiapkan peserta didik dalam melakukan tes akhir hasil belajar. Peneliti melakukan tes akhir hasil belajar setelah kedua kelas diberikan perlakuan, sehingga didapatkan bahwa rata-rata nilai hasil belajar fisika peserta didik pada kelas eksperimen sebesar 80,57 dengan nilai tertinggi 96,00 , sedangkan nilai rata-rata kelas kontrol sebesar 75,60 dengan nilai tertinggi 88,00. Nilai rata-rata tes akhir menunjukkan bahwa terdapat peningkatan hasil belajar fisika peserta didik terhadap nilai yang diperoleh sebelumnya. Kemudian dilakukan uji homogenitas dan uji normalitas data hasil tes akhir. Berdasarkan hasil uji homogenitas dan uji normalitas data hasil tes akhir didapatkan bahwa kedua kelas homogen dan terdisribusi normal, selanjutnya dilakukan uji hipotesis dengan menggunakan uji statistik (uji-t), diperoleh nilai $t_{\text {hitung }}$ lebih besar dari $t_{\text {tabel }}$ dengan harga $t_{\text {hitung }}=4,12, \quad t_{\text {tabel }}=2.02$. Hal ini menunjukkan bahwa terdapat pengaruh penggunaan media simulasi PhET (Physics Education Technology) terhadap hasil belajar fisika peserta didik pada kelas eksperimen dengan kelas kontrol yang menggunakan pembelajaran konvensional.

Tabel 1. Hasil Tes Awal dan Tes Akhir Sampel

\begin{tabular}{ccccc}
\hline \multirow{2}{*}{$\begin{array}{c}\text { Tes Awal } \\
\text { en }\end{array}$} & $\begin{array}{c}\text { Kelas } \\
\text { Eksperim } \\
\text { en }\end{array}$ & $\begin{array}{c}\text { Kelas } \\
\text { Kontr } \\
\text { ol }\end{array}$ & $\begin{array}{c}\text { Telas Akperim } \\
\text { en }\end{array}$ & $\begin{array}{c}\text { Kelas } \\
\text { Kontr } \\
\text { ol }\end{array}$ \\
\hline $\begin{array}{c}\text { Jumlah } \\
\text { Peserta } \\
\text { didik }\end{array}$ & 21 & 20 & 21 & 20 \\
$\quad$ Nilai \\
$\begin{array}{c}\text { Tertinggi } \\
\text { Nilai }\end{array}$ & 44 & 48 & 96 & 88 \\
$\begin{array}{c}\text { Terenda } \\
\text { h }\end{array}$ & 16 & 20 & 68 & 64 \\
Rata-rata & 30,10 & 33,20 & 80,57 & 75,60 \\
\hline
\end{tabular}

Berdasarkan Tabel 1. tes awal terlihat bahwa kemampuan awal peserta didik antara kelas eksperimen dan kelas kontrol tidak memiliki perbedaan yang jauh sehingga dapat dikategorikan sama. Dapat dijelaskan bahwa terdapat peningkatan hasil belajar fisika peserta didik pada kelas eksperimen dan kelas kontrol. Hal ini ditandai dengan adanya kenaikan nilai rata-rata peserta didik setelah diberi perlakuan. Untuk kelas ekperimen mengalami kenaikan sebesar 50,47 sedangkan untuk kelas kontrol mengalami peningkatan sebesar 42,40. Berikut digambarkan peningkatan hasil belajar peserta didik dalam bentuk grafik pada Gambar 1 .

Berdasarkan hasil penelitian yang sudah dilakukan didapatkan bahwa nilai rata-rata tes akhir hasil belajar lebih tinggi dibandingkan dengan tes awal, baik pada kelas eksperimen maupun kelas kontrol mengalami peningkatan, namun peningkatan hasil belajar pada kelas eksperimen lebih tinggi dibandingkan dengan kelas kontrol. Terdapat beberapa faktor yang mempengaruhi diantaranya, yaitu pada kelas eksperimen menggunakan media simulasi PhET (Physics Education Technology), dengan adanya media simulasi PhET dapat menarik perhatian peserta didik untuk lebih antusias dalam mengikuti proses pembelajaran. Media simulasi PhET juga dapat digunakan dengan mudah oleh peserta didik dalam melakukan percobaan hukum hooke secara ideal tanpa takut terjadi kerusakan pada alat dan bahan yang digunakan dalam laboratorium nyata. Seperti yang diungkapkan oleh [9] simulasi PhET dapat melakukan percobaan secara ideal, yang tidak dapat digunakan dengan menggunakan alat dan bahan yang sesungguhnya. Keberhasilan dalam pembelajaran tidak hanya disebabkan oleh penggunaan media simulasi PhET, akan tetapi faktor seperti materi pembelajaran, LKPD, dan latihan soal yang diberikan kepada 
peserta didik juga memberikan peran dalam meningkatnya hasil belajar peserta didik.

Hasil penelitian ini diperkuat oleh beberapa penelitian sebelumnya, diantaranya penelitian yang dilakukan oleh Zahara, dkk [4] menyimpulkan bahwa pembelajaran dengan penggunaan $\mathrm{PhET}$ (Physics Education Technology) dapat meningkatkan hasil belajar fisika peserta didik. Karena pembelajaran dengan media PhET dapat melibatkan peserta didik dalam aktivitas pembelajaran yang memerlukan keterampilan kognitif yang lebih tinggi. Nurhayati, dkk [2] menyatakan hasil belajar peserta didik yang diajarkan dengan metode demonstrasi berbantu media animasi Software PhET lebih baik dari pada hasil belajar peserta didik dengan menggunakan metode konvensional. Mubarok [15] menyatakan bahwa menerapkan pembelajaran fisika dengan menggunakan media PhET Simulations hasil belajarnya lebih baik daripada kelas yang hanya menggunakan praktikum saja tanpa disertai penggunaan media PhET. Purwanto [7] juga menyatakan bahwa menggunakan media PhET Simulations hasil belajarnya lebih baik daripada kelas yang hanya menggunakan alat peraga. Hal ini disebabkan pembelajaran yang menggunakan media simulasi PhET dapat menjelaskan secara terperinci daripada pembelajaran yang menggunakan alat peraga. Yuafi [3] menyimpulkan bahwa terdapat pengaruh penerapan model pembelajaran langsung yang menggunakan media pembelajaran Physics Education Technology (PhET) terhadap hasil belajar fisika peserta didik.

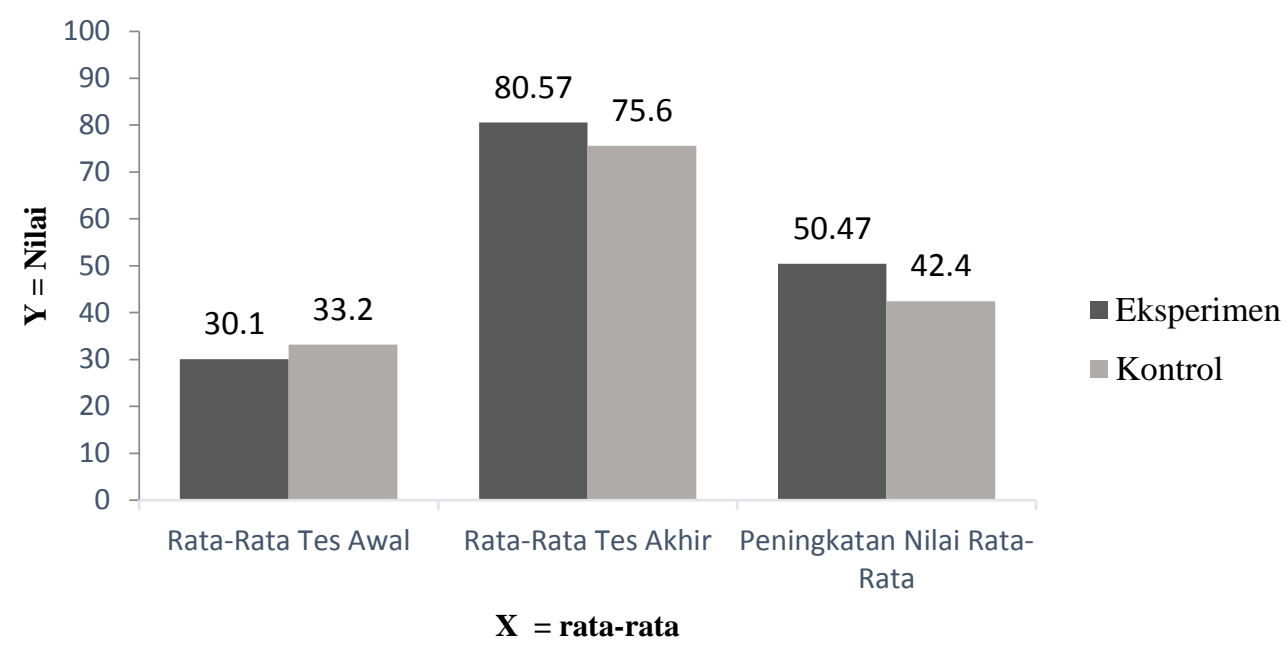

Gambar 1. Perbandingan Peningkatan Rata-rata Hasil Belajar

\section{KESIMPULAN}

Berdasarkan rumusan masalah, hasil penelitian yang didapat, dan pembahasan maka dapat disimpulkan bahwa, ada pengaruh penggunaan media simulasi PhET (Physics Education Technology) terhadap hasil belajar fisika peserta didik pada kelas XI MIA SMA Negeri 1 Kediri Kabupaten Lombok Barat tahun pelajaran 2018 /2019.

\section{DAFTAR PUSTAKA}

[1] Gunawan. 2015. Model pembelajaran sains berbasis ICT. Mataram: FKIP Universitas Mataram. Hal 3 - 13.

[2] Nurhayati, Fadilah, S, \& Mutmainnah. 2014. Penerapan Metode Demonstrasi Berbantu Media Animasi Software PhET Terhadap Hasil Belajar Siswa Dalam Materi Listrik Dinamis Kelas X Madrasah Aliyah Negeri 1 Pontianak. Jurnal Pendidikan Fisika Dan Aplikasinya. 4 (2), 1-7.

[3] Yuafi, M.E.D, \& Endryansyah. 2015. Pengaruh Penerapan Media Pembelajaran PhET (Physics Educations Technology)
Simulation Terhadap Hasil Belajar Siswa Kelas X TITL Pada Standar Kompetensi Mengaplikasikan Rangkaian Listrik di SMKN 7 Surabaya. Jurnal Pendidikan Elektro UNESA. 04 (02), 407-414.

[4] Zahara, S.R, Yusrizal, \& Rahwanto, A. 2015. Pengaruh Penggunaan Media Komputer Berbasis Simulasi Physics Education Technology (PhET) Terhadap Hasil Belajar dan Keterampilan Berfikir Kritis Siswa Pada Materi Fluida Statis. Jurnal Pendidikan Sains Indonesia. 03 (01), 251-258.

[5] Arifin, Z dan Setiyawan, A. 2012. Pengembangan Pembelajaran Aktif Dengan ICT. Yogyakarta: Skripta Media Kreatif. Hal 124.

[6] Noah, Finkelstein. 2006. Higtech Tools Fot Teaching Physics Education Technology Project. Merlot Journal Of Online Learning And Teaching. 2 (3). 110-121.

[7] Purwanto, A.E, Hendri,M \& Susanti, N. 2016. Studi Perbandingan Hasil Belajar Siswa Menggunakan Media PhET Simulations Dengan Alat Peraga Pada Pokok Bahasn 
Listrik Maghnet di Kelas IX SMPN 12 Kabupaten Tebo. Jurnal Edu Fisika. 01 (01), 22-27.

[8] Sugiarti. 2015. Pembelajaran Fisika Berbantuan Simulasi Phet dalam Membangun Konsep Siswa. Wahana DIDAKTIKA, Jurnal Ilmu Kependidikan. 13 (1): 1-135.

[9] Fithriani, S.L., Halim, A \& Khaldun, I. 2016. Penggunaan Meia Simulasi PhET Dengan Pendekatan Inkuiri Terbimbing Untuk Meningkatkan Keterampilan Berfikir Kritis Siswa Pada Pokok Bahasan Kalor Di SMA Negeri 12 Banda Aceh. Jurnal Pendidikan Sains Indonesia. 4 (2) : 45-52.

[10] Rahmawati, T \& Daryanto. 2015. Teori Belajar dan Proses Pembelajaran yang Mendidik. Yogyakarta: Gava Media. Hal 36.

[11] Khadira, L,A. Rusilowati, A, \& Pratiknyo, K. 2009. Penerapan Model Berbasis Masalah
Untuk Peningkatan Hasil Belajar Siswa Pada Pokok Bahasan Elastisitas Bahan. Jurnal pendidikan fisika indonesia. 5 : 83-89.

[12] Suprijono, A. 2010. Cooperative Learning Teori dan Aplikasi PAIKEM. Yogyakarta: Pustaka Pelajar. Hal 5.

[13] Nanang, H dan Suhana,.C. 2010. Konsep Strategi Pembelajaran. Bandung: PT Refika Aditama. Hal 21-22.

[14] Setyosari, P. 2013. Metode Penelitian Pendidikan dan Pengembangan Edisi Ketiga. Jakarta: Kencana Prenadamedia Group. Hal 45-197.

[15] Mubarok, M.F \& Mulyaningsih, S. 2014. Penerapan Pembelajaran Fisika Pada Materi Cahaya Dengan Media PhET Simulations Untuk Meningkatkan Pemahaman Konsep Siswa Di SMP. Jurnal Inovasi Pendidikan Fisika. 03 (1), 76-80. 